\title{
Artículo Especial: Obras maestras del arte universal y la medicina: Calígula, de Albert Camus (1913 -1960)
}

\author{
Universal Art Masterpieces and Medicine: Calígula by Alber Camus (1913 -1960)
}

Carlos Musso*

\begin{abstract}
Argumento
Calígula, emperador de la nación más poderosa de su época, se plantea que si el absurdo representa la esencia del mundo, es su rol como todopoderoso llevar esta lógica hasta sus últimas consecuencias.

Sus caprichos devienen entonces su único código de conducta, tomando decisiones de gobierno e impartiendo suplicios a sus vasallos sin ton ni son.

Finalmente, pese a ser advertido de la existencia de un complot en su contra, no sólo no hace nada para detenerlo, sino que lo alienta hasta ser asesinado.
\end{abstract}

\section{Ejemplos del texto}

..."cuando todas las explicaciones son posibles, no hay en verdad motivos para no elegir la más trivial o la más tonta..." "...este mundo no tiene importancia, y quien así lo entienda conquista su libertad..."

\section{Comentario}

En un artículo previo basado en la obra de teatro "La vida es sueño" de Calderón de la Barca habíamos descripto uno de los componentes de la naturaleza humana: la sombra.

Ahora, en el análisis de la presente obra, Calígula de Camus, haremos hincapié en otro de los componentes de dicha naturaleza: el absurdo.

El absurdo es esa sensación de desasosiego nacida de vivenciar la contradicción entre aquello que sería esperable a la luz de la razón y aquello que en realidad es; siendo así mismo uno de los atributos de la conducta humana. Sin embargo, este componente irracional del comportamiento humano, es en realidad una prolongación del sinsentido del mundo, el cual lo alcanza y atraviesa. Dado que el mundo es irracional, carente de propósito alguno y ajeno a los deseos humanos, la falta de correspondencia entre aquello que el hombre anhela y aquello que la realidad le ofrece, nace simplemente de pretender el hombre atribuirle al mundo un sentido del cual carece. Se entiende entonces que si la esencia del mundo es absurda, mal puede el hombre ser ajeno a ella.
Tal es así, que cotidianamente comprobamos que en la misma mente humana que pretende la existencia de un mundo lógico y predecible, coexisten mecanismos de pensamiento mágicofantástico. Si un médico asistencial comprende la presencia del absurdo humano será capaz de entender por qué un paciente puede asistir a una consulta en busca de una solución a una afección, y luego absurdamente desatender el tratamiento prescripto. Ante una situación de este tipo, la actitud de un profesional consustanciado con los conceptos antes desarrollados no será entonces enfadarse con su paciente, sino tratar de entender cual es la lógica que sustenta ese absurdo para procurar luego desarticularla.

Es así que la comprensión de la existencia de la absurdidad del mundo, de ninguna manera significa resignarse a su padecimiento, y lejos de tener una connotación negativa, implica una gran ventaja, pues al carecer la vida de un propósito preestablecido, se cuenta entonces con la libertad y la responsabilidad de forjarlo.

Dominar el absurdo significa neutralizarlo mediante el ejercicio de la coherencia, así como seguir adelante a pesar de haber entendido el sinsentido del mundo, constituye una actitud madura, a la que Camus llamó lúcida indiferencia.

\section{Conclusión}

La obra Calígula de Albert Camus constituye una excelente oportunidad para comprender las raíces del absurdo humano y la importancia del ejercicio de la coherencia en su neutralización.

\section{Referencias}

Amalfi F. El taller de los escritores. Barcelona. Océano. 2005

Artaud A. El ombligo de los limbos. Buenos Aires. Aquarius. 1972

Buñuel L, Dali S. Un perro andaluz.1928 (film)

Buñuel L, Dali S. La edad de oro. 1930 (film)

Camus A. Camus. Buenos Aires. Losada 1976

Rigobello A. Camus. Buenos Aires. Columba. 1961 